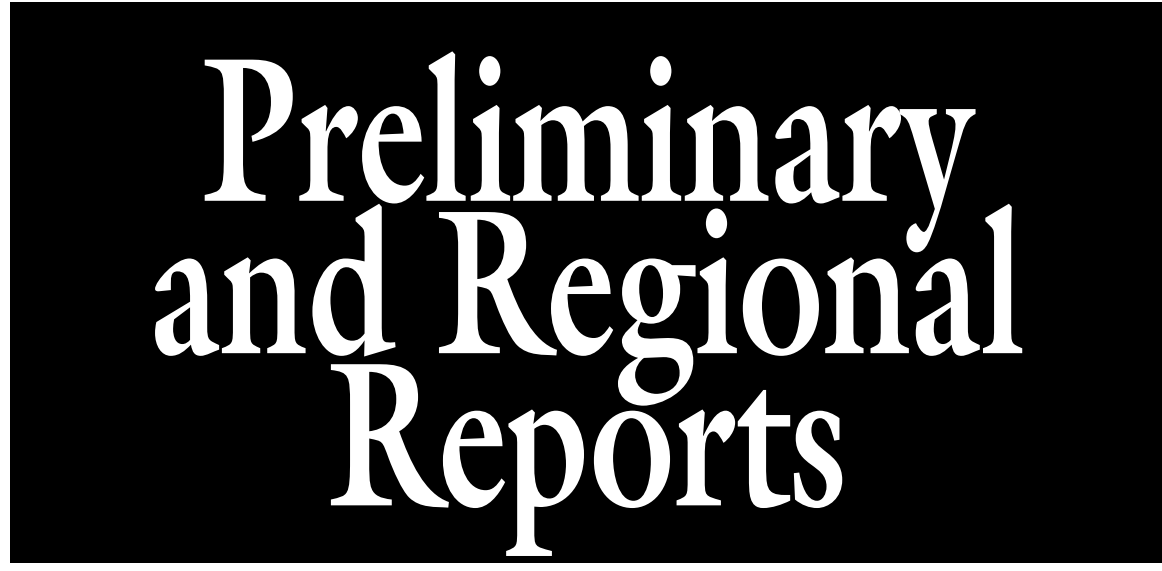

\section{Growth and Quality Response of Woody Shrubs to Nitrogen Fertilization Rates during Landscape Establishment in Florida}

\author{
Amy L. Shober ${ }^{1,7,13}$, Kimberly A. Moore ${ }^{2,8}$, Nancy G. West ${ }^{3,9}$, \\ Christine Wiese ${ }^{4,10}$, Gitta Hasing ${ }^{3,9}$, Geoffrey Denny ${ }^{5,11}$, \\ and Gary W. Knox ${ }^{6,12}$
}

AdDitional INDEX wORDs. landscape maintenance, visual quality, woody ornamental plants

Summary. Despite inconsistent reports of nitrogen $(\mathrm{N})$ fertilization response on growth of landscape-grown woody ornamentals, broad $\mathrm{N}$ fertilization recommendations exist in the literature. The objective of this research was to evaluate the growth and quality response of three landscape-grown woody shrub species to $\mathbf{N}$ fertilizer. Three ornamental shrub species, 'Alba' indian hawthorn (Raphiolepis indica), sweet viburnum (Viburnum odoratissimum), and 'RADrazz' (Knock Out $\left.{ }^{\mathrm{TM}}\right)$ rose $($ Rosa $)$ were transplanted into field soils in central Florida (U.S. Department of Agriculture hardiness zone 9a). Controlled-release $\mathbf{N}$ fertilizer was applied at an annual $\mathrm{N}$ rate of $0,2,4,6$, and $12 \mathrm{lb} / 1000 \mathrm{ft}^{2}$ for 100 weeks. Plant size index measurements, SPAD readings (a measure of greenness), and visual quality ratings were completed every month through 52 weeks after planting (WAP) and then every 3 months through 100 WAP. Plant tissue total Kjeldahl N (TKN) concentrations and shoot biomass were measured at $100 \mathrm{WAP}$. Results of regression analysis indicated little to no plant response (size index, biomass, SPAD) to $\mathbf{N}$ fertilizer rate. Shrub quality was acceptable for all species through 76 WAP regardless of the $\mathrm{N}$ fertilization rate. However, quality of rose and sweet viburnum fertilized with $\mathrm{N}$ at the low rates $\left(<2 \mathrm{lb} / 1000 \mathrm{ft}^{2}\right)$ was less than acceptable ( $<3$ out of 5 ) after 76 WAP. Results suggest that posttransplant applications of fertilizer may not increase plant growth, but that low-to-moderate levels of $\mathrm{N}$ fertilization ( 2 to $4 \mathrm{lb} / 1000 \mathrm{ft}^{2}$ per year) may help plant maintain quality postestablishment.

$\mathrm{F}$ ertilization requirements for establishment of shrubs in the landscape have received limited attention in part because woody dicots often perform well with little or no supplemental fertilizer (Broschat et al., 2008). However, much of the available research evaluating the growth response of woody ornamentals to $\mathrm{N}$ fertilization has reported variable results. Ferrini and Baietto (2006) found and restricted space for root growth. Similarly, Gilman and Yeager (1990) saw no effect of $\mathrm{N}$ rate on caliper diameter of laurel oak (Quercus laurifolia) and japanese ligustrum (Ligustrum japonicum) under field conditions. In contrast, some researchers have reported increases in growth rate (Gilman et al., 2000), height (Gilman and Yeager, 1990; Gilman et al., 2000), and overall size (Lloyd et al., 2006; Neely, 1980; Schulte and Whitcomb, 1975) as a result of fertilizer applications. In addition, Rose and Biernacka (1999) found that $\mathrm{N}$ fertilization rate influenced tissue nutrient contents, dry weight, and shoot-to-root ratio of freeman maple (Acer $\times$ freemanii). Tissue N, phosphorus ( $\mathrm{P})$, and potassium $(\mathrm{K})$ accumulation during the growing season were correlated with dry weight accumulation and increased with time. However, rapid tree growth as a response to $\mathrm{N}$ fertilizer has also been associated with reduced drought tolerance and greater insect populations (Lloyd et al., 2006).

Several studies produced conflicting results on the benefit of applying fertilizer to woody ornamentals in the first years after planting. For example, van de Werken and Warmbrod (1969) determined that fertilizer had little effect on the growth rate of sugar maple (Acer saccharum), tulip tree (Liriodendron tulipifera), and pin oak (Quercus palustris) until the third year after planting. The authors found no differences in tree growth because of fertilizer treatments after 3 years for any species, but trees receiving $\mathrm{N}$ at an annual rate of 60 and $120 \mathrm{lb} /$ acre had significantly greater growth (e.g., height, spread, and trunk diameter) than those receiving no $\mathrm{N}$ fertilizer after 8 years. Nitrogen fertilizer rate effects on sugar maple, tulip tree, and pin oak growth were even greater 11 years after planting, with trees receiving $120 \mathrm{lb} /$ acre annual $\mathrm{N}$ producing the most growth (van de Werken, 1981). In contrast, total new growth of sugar maple planted in a clay loam soil increased as $\mathrm{N}$ increased in the first growing season (Schulte and Whitcomb, 1975). Similarly, Lloyd et al. (2006) reported that tree growth during the first year after planting into the landscape was positively correlated with $\mathrm{N}$ concentrations in plant tissue when they were treated in the nursery; however, the $\mathrm{N}$ fertilizer growth response did not 
carry over into the following year of the study.

Though growth response of landscape-grown woody ornamentals to $\mathrm{N}$ fertilizers can be highly variable, a variety of sources provide generalized $\mathrm{N}$ rate recommendations for tree and shrub fertilization. For example, Rose (1999) summarized N fertilizer recommendations that were based on research conducted during the 1950s through the $1970 \mathrm{~s} ; \mathrm{N}$ rate recommendations for fertilization of field-grown ornamentals ranged from $\mathrm{l}$ to $6 \mathrm{lb} / 1000 \mathrm{ft}^{2}$. The Florida Friendly ${ }^{\mathrm{TM}}$ Landscaping Program provides annual $\mathrm{N}$ fertilizer recommendations for ornamentals growing in low (0 to $2 \mathrm{lb} / 1000 \mathrm{ft}^{2}$ ), medium ( 2 to $4 \mathrm{lb} / 1000 \mathrm{ft}^{2}$ ), and high (4 to $6 \mathrm{lb} / 1000 \mathrm{ft}^{2}$ ) maintenance landscapes (Florida Department of Environmental Protection, 2010); no guidance for selecting a maintenance level is provided. More broadly, the American National Standards Institute (ANSI) A300 Tree Fertilization Standards (ANSI, 2004) recommend using a slow-release fertilizer at $\mathrm{N}$ rates between 2 and $4 \mathrm{lb} / 1000 \mathrm{ft}^{2}$ per year, not to exceed $6 \mathrm{lb} / 1000 \mathrm{ft}^{2}$ per year or quick-release (soluble) fertilizer at $\mathrm{N}$ rates between 1 and 2 $\mathrm{lb} / 1000 \mathrm{ft}^{2}$ per application, not to exceed $4 \mathrm{lb} / 1000 \mathrm{ft}^{2}$ per year. Additional research is needed to evaluate

The work was supported by the Florida Agricultural Experiment Station, the Southwest Florida Water Management District, and the Florida Nursery Growers and Landscape Association.

${ }^{1}$ Department of Plant and Soil Sciences, University of Delaware, 531 South College Avenue, Newark, DE 19716

${ }^{2}$ Environmental Horticulture Department, University of Florida, IFAS, Fort Lauderdale REC, 3205 College Avenue, Davie, FL 33314

${ }^{3}$ Environmental Horticulture Department, University of Florida, IFAS, Gulf Coast REC, 14625 CR 672, Wimauma, FL 33598

${ }^{4}$ Environmental Horticulture Department, University of Florida, IFAS, PO Box 110675, Gainesville, FL 32611

${ }^{5}$ Mississippi State University, 246 Dorman Hall, Mississippi State, MS 39762

${ }^{6}$ Environmental Horticulture Department, University of Florida, IFAS, North Florida REC, 155 Research Road, Quincy, FL 32351

${ }^{7}$ Assistant Professor.

${ }^{8}$ Professor.

${ }^{9}$ Biologist.

${ }^{10}$ Biologist.

${ }^{11}$ Assistant Extension Professor.

${ }^{12}$ Professor.

${ }^{13}$ Corresponding author. E-mail ashober@udel.edu. these published fertilizer rate recommendations. The objective of this research was to evaluate the growth and quality response of three landscapegrown woody shrub species to $\mathrm{N}$ fertilizer applied at five rates. Nitrogen fertilizer response results will be used to develop $\mathrm{N}$ fertilization recommendations that reduce fertilizer applications to prevent $\mathrm{N}$ losses to groundwater without sacrificing plant growth and quality.

\section{Materials and methods}

Plant Materials AND EXPERIMENTAL DESIGN. Three ornamental shrub species ('Alba' indian hawthorn, sweet viburnum, and 'RADrazz' rose) were selected for evaluation across a range of $\mathrm{N}$ fertilization regimes in 2009. Shrubs were received from Harrell's Nursery (Plant City, FL) in 3 -gal pots on 22 May 2009. Fifteen planting beds $(4 \times 54 \mathrm{ft})$ were established in central Florida [U.S. Department of Agriculture (USDA) hardiness zone 9a] at the University of Florida-Institute of Food and Agricultural Sciences Gulf Coast Research and Education Center in Wimauma, FL. Shrubs were planted in an existing field containing a mosaic of Zolfo fine sand (sandy, siliceous, hyperthermic Oxyaquic Alorthods) and Seffner fine sand [sandy, siliceous, hyperthermic Aquic Humic Dystrudepts (USDA, 2004)]. An initial composite soil sample was collected from the top 0 to 6 inches of the study area, air-dried, passed through a $2-\mathrm{mm}$ screen, and analyzed for soil $\mathrm{pH}$ ( $1: 2$ soil to deionized water ratio), Mehlich $\mathrm{l} \mathrm{P}, \mathrm{K}$, calcium $(\mathrm{Ca})$, magnesium $(\mathrm{Mg})$, zinc $(\mathrm{Zn})$, copper $(\mathrm{Cu})$, manganese $(\mathrm{Mn})$, and iron $(\mathrm{Fe})[\mathrm{l}: 4$ ratio of soil to $0.0125 \mathrm{M}$ sulfuric acid $\left(\mathrm{H}_{2} \mathrm{SO}_{4}\right)+$
$0.05 \mathrm{M}$ hydrochloric acid $(\mathrm{HCl})$ (Mylavarapu, 2009)], and soil inorganic N (Mulvaney, 1996). Mehlich 1 nutrients were analyzed using inductively coupled plasma-atomic emission spectroscopy (Perkin Elmer, Waltham, MA). Colorimetric analysis of soil nitrate + nitrite $\left(\mathrm{NO}_{3}+\mathrm{NO}_{2}-\mathrm{N}\right)$ [U.S. Environmental Protection Agency (USEPA), 1993a] and ammonium $\left(\mathrm{NH}_{4}-\mathrm{N}\right)(\mathrm{USEPA}, 1993 \mathrm{~b})$ was completed using a discrete analyzer (AQ2; Seal Analytical, Mequon, WI). The mean initial soil $\mathrm{pH}$ was 6.79 and Mehlich $1 \mathrm{P}, \mathrm{K}, \mathrm{Ca}, \mathrm{Mg}, \mathrm{Zn}, \mathrm{Mn}$, and Cu were 239, 58.1, 1362, 87.8, 13.8, 8.28 , and $18.0 \mathrm{mg} \cdot \mathrm{kg}^{-1}$, respectively; Mehlich $1 \mathrm{Fe}$ concentrations were below the detection limit $\left(<4.0 \mathrm{mg} \cdot \mathrm{kg}^{-1}\right)$. Initial soil concentrations of $\mathrm{NO}_{3}+$ $\mathrm{NO}_{2}-\mathrm{N}$ and $\mathrm{NH}_{4}-\mathrm{N}$ were 1.46 and $3.95 \mathrm{mg} \cdot \mathrm{kg}^{-1}$, respectively. Soil $\mathrm{pH}$ was adjusted to $\mathrm{pH} 6.5$ before planting and annually using dolomitic lime (Lawn and Garden Lime; Sunniland Corp., Sanford, FL) at the recommended rate based on results of the Adams-Evans lime requirement test (Mylavarapu, 2009).

Plants were transplanted into each field plot with 6-ft spacing between plants and 12 -ft spacing between rows on 15 to 17 June 2009 . A total of three shrubs of each species were planted in each plot. Controlledrelease fertilizer was broadcast applied to the shrub bed at annual $\mathrm{N}$ rates of $0,2,4,6$, and $12 \mathrm{lb} / 1000 \mathrm{ft}^{2}$ to correspond with the Florida Friendly Landscaping ${ }^{\mathrm{TM}}$ Program recommendations for landscape fertilization (Florida Department of Environmental Protection, 2010); double the highest recommended $\mathrm{N}$ rate (12 $\mathrm{lb} / 1000 \mathrm{ft}^{2}$ ) was included to represent overfertilization. Shrubs were fertilized every 12 weeks with a polymer-coated urea fertilizer (Polyon

\begin{tabular}{llll}
\hline $\begin{array}{l}\text { Units } \\
\text { To convert U.S. to SI, } \\
\text { multiply by }\end{array}$ & U.S. unit & SI unit & $\begin{array}{l}\text { To convert SI to U.S., } \\
\text { multiply by }\end{array}$ \\
\hline 29.5735 & $\mathrm{fl} \mathrm{oz}$ & $\mathrm{mL}$ & 0.0338 \\
0.3048 & $\mathrm{ft}$ & $\mathrm{m}$ & 3.2808 \\
0.0283 & $\mathrm{ft}^{3}$ & $\mathrm{~m}^{3}$ & 35.3147 \\
3.7854 & gal & $\mathrm{L}$ & 0.2642 \\
2.54 & inch $(\mathrm{es})$ & $\mathrm{cm}$ & 0.3937 \\
25.4 & inch $(\mathrm{es})$ & $\mathrm{mm}$ & 0.0394 \\
48.8243 & $\mathrm{lb} / \mathrm{l} 000 \mathrm{ft}^{2}$ & $\mathrm{~kg} \cdot \mathrm{ha}^{-1}$ & 0.0205 \\
1.1209 & $\mathrm{lb} / \mathrm{acre}$ & $\mathrm{kg} \cdot \mathrm{ha}^{-1}$ & 0.8922 \\
305.1517 & $\mathrm{oz} / \mathrm{ft}^{2}$ & $\mathrm{~g} \cdot \mathrm{m}^{-2}$ & 0.0033 \\
1 & $\mathrm{ppm}$ & $\mathrm{mg} \cdot \mathrm{kg}^{-1}$ & 1 \\
$\left({ }^{\circ} \mathrm{F}-32\right) \div 1.8$ & ${ }^{\circ} \mathrm{F}$ & ${ }^{\circ} \mathrm{C}$ & $\left({ }^{\circ} \mathrm{C} \times 1.8\right)+32$
\end{tabular}


42N-0P-0K; Harrell's, Lakeland, FL) containing $33.6 \%$ slow-release $\mathrm{N}$. The fertilization timing for the polymercoated urea fertilizer was based on the release-rate curve supplied by the manufacturer. Other nutrients were applied to individual plots periodically at the University of FloridaInstitute of Food and Agricultural Sciences recommended rates based on results of a routine soil test (Kidder et al., 2009). Triple superphosphate fertilizer $(0 \mathrm{~N}-20 \mathrm{P}-0 \mathrm{~K}$; manufacturer unknown) was applied at a $\mathrm{P}$ rate of $0.3 \mathrm{lb} / 1000 \mathrm{ft}^{2}$ per year to the plots receiving the 4 and $6 \mathrm{lb} / 1000 \mathrm{ft}^{2}$ $\mathrm{N}$ fertilizer treatment in block 1 on 26 Feb. 2010 and 20 Aug. 2010. A micronutrient fertilizer containing sulfur (S), boron (B), $\mathrm{Cu}, \mathrm{Fe}, \mathrm{Mn}$, molybdenum (Mo), and Zn (Scotts MicroMax $^{\circledR}$; Scotts, Marysville, $\mathrm{OH}$ ) was applied to at the label recommended rate to block 1 plots receiving the 4 and $6 \mathrm{lb} / 1000 \mathrm{ft}^{2} \mathrm{~N}$ fertilizer treatment on 26 Feb. 2010 and block 1 plots receiving the 4,6 , and $12 \mathrm{lb} /$ $1000 \mathrm{ft}^{2} \mathrm{~N}$ fertilizer treatment on 27 Jul. 2010. Potassium sulfate fertilizer (0N-0P-41.5K-17S; Great Salt Lake Minerals Corp., Overland Park, KS) was applied to all plots on 10 Sept. 2010 at a Krate of $1.2 \mathrm{lb} / 1000$ $\mathrm{ft}^{2}$. All roses received two foliar applications of liquid $\mathrm{Fe}$ [iron sulfate (Liquid Iron, Sunniland Corp.)] at a rate of $30 \mathrm{~mL} / \mathrm{gal}$ (total of $2.5 \mathrm{gal}$ applied) on 10 Mar. 2010 and 31 Mar. 2010 to correct an Fe deficiency. Plots were not mulched to minimize outside $\mathrm{N}$ contributions. Weeds were removed manually or spot treated with glyphosate (Round-Up ${ }^{\circledR}$; Monsanto, Creve Coeur, $\mathrm{MO}$ ).

Irrigation was applied to each individual plant through two spray stakes (Netafim USA, Fresno, CA) spaced 15 inches apart. Plants were irrigated four times per week, one row at a time, between 0000 and $0700 \mathrm{HR}$, to apply 3.8 gal of water per plant per irrigation event for a period of 3 months. Starting 5 Oct. 2009, irrigation was reduced to three times per week, with each plant receiving a total of $2.7 \mathrm{gal}$ of water until 4 Jan. 2010 (28 WAP), at which time plants were considered established (Shober et al., 2009b). Once established, irrigation was then applied as needed during prolonged periods without significant rainfall. Cumulative rainfall was 86.5 inches from 18 June
2009 to 8 June 2011 (University of Florida, 2013).

Plant SIZE INDEX AND Biomass. Plant size measurements were taken at planting, monthly until 52 WAP, and every 3 months until 100 WAP. Size index (SI) was used as a quantitative indicator of plant growth. Size index was calculated as follows: SI (cubic meters) $=\mathrm{H} \times \mathrm{Wl} \times \mathrm{W} 2$, where $\mathrm{H}$ is the plant height (meters), $\mathrm{Wl}$ is the widest width of the plant (meters), and W2 is the width perpendicular to the widest width (meters). Shoot biomass was determined by harvesting all aboveground biomass (leaves and stems) at 100 WAP. Plant shoots were dried to a constant weight at $40.5^{\circ} \mathrm{C}$ and weighed to determine shoot dry weight (grams).

Plant SPAD values. The reflective greenness of plant leaves was measured for all plants by averaging readings from three recently matured (midsection) leaves per plant using a portable SPAD-502 m (Minolta Corp., Ramsey, NJ). Plant SPAD readings were taken monthly for the first year and then every 3 months for the remainder of the study.

Foliar NUTRIENT ANALYsis. The youngest fully expanded leaves were collected from all treatments every 3 months. Tissue samples from the three individual plants of each species were combined to create a single composite sample for each species in each plot, which generated three replicate composite samples for each species and $\mathrm{N}$ fertilizer treatment. Tissue samples were ground to pass a number 20 screen using a Wiley mill (Arthur H. Thomas Co. Scientific, Philadelphia, PA) and dried at $110^{\circ} \mathrm{C}$ for $7 \mathrm{~d}$. Digested tissue samples (Mylavarapu, 2009) were analyzed for TKN by EPA Method 351.2 (USEPA, 1993c) using an autoanalyzer (Alpkem Flow IV; Pulse Instrumentation, Saskatoon, SK, Canada).

Plant Quality Ratings. Visual quality ratings were assigned for each plant monthly through 54 WAP and every 3 months through 100 WAP. Canopy density, flower cover, chlorosis, and dieback were considered in assigning plants a quality rating of 0 to 5 . Dead plants were assigned a rating of 0 , average-quality plants with limited dieback or chlorosis were assigned a rating of 3 , and outstanding quality plants with high canopy density, high-quality flowers, and no nutrient deficiencies or dieback were assigned a rating of 5 (Shober et al., 2009a).

Statistical analysis. The experiment was arranged in a randomized complete block design with $5 \mathrm{~N}$ fertilizer rates applied randomly over 15 landscape field plots. Nitrogen fertilizer treatments were replicated three times by randomly assigning each $\mathrm{N}$ rate to plots within each field block. Within each plot, three individual plants of each shrub species were planted. Plant growth parameter measurements (SI, SPAD, biomass, and tissue TKN) for all the three shrubs of each species planted were averaged to obtain a mean value for each species within each plot (replicate). Regression analysis was completed using PROC REG (SAS Version 9.3; SAS Institute, Cary, NC) to evaluate growth response of each species to $\mathrm{N}$ fertilization rate using the mean response data for plot at each collection date. First-order (linear) and second-order (polynomial) regression models were fit by species and WAP using $\mathrm{N}$ rate and $\mathrm{N}$ rate $\times$ $\mathrm{N}$ rate as the predictor variables. The regression model was considered significant at the $P<0.05$ level. If the $\mathrm{N}$ rate $\times \mathrm{N}$ rate term was significant (based on a $t$ test with $P<0.05$ ), then the second-order regression equation was selected in lieu of the first-order regression and the optimum $\mathrm{N}$ rate for each regression fit was determined by the maximum point on the regression curve, which was determined by solving the second-order derivative of the equation. The optimum $\mathrm{N}$ rate exceeded the $12 \mathrm{lb} / 1000 \mathrm{ft}^{2}$ if the first-order (linear) regression equation was significant. Plant quality data were analyzed by species and WAP using PROC GLIMMIX (SAS Version 9.3) with $\mathrm{N}$ rate included as a fixed effect. Normality of all data was validated using histogram and normality plots of the conditional residuals. All pairwise comparisons were conducted with the Tukey honestly significant difference test at a significance level of $\alpha=0.05$.

\section{Results}

Plant size index and biomass. Neither regression model (i.e., firstor second-order polynomial) adequately described the SI or biomass response of indian hawthorne or viburnum (data not shown). In contrast, 

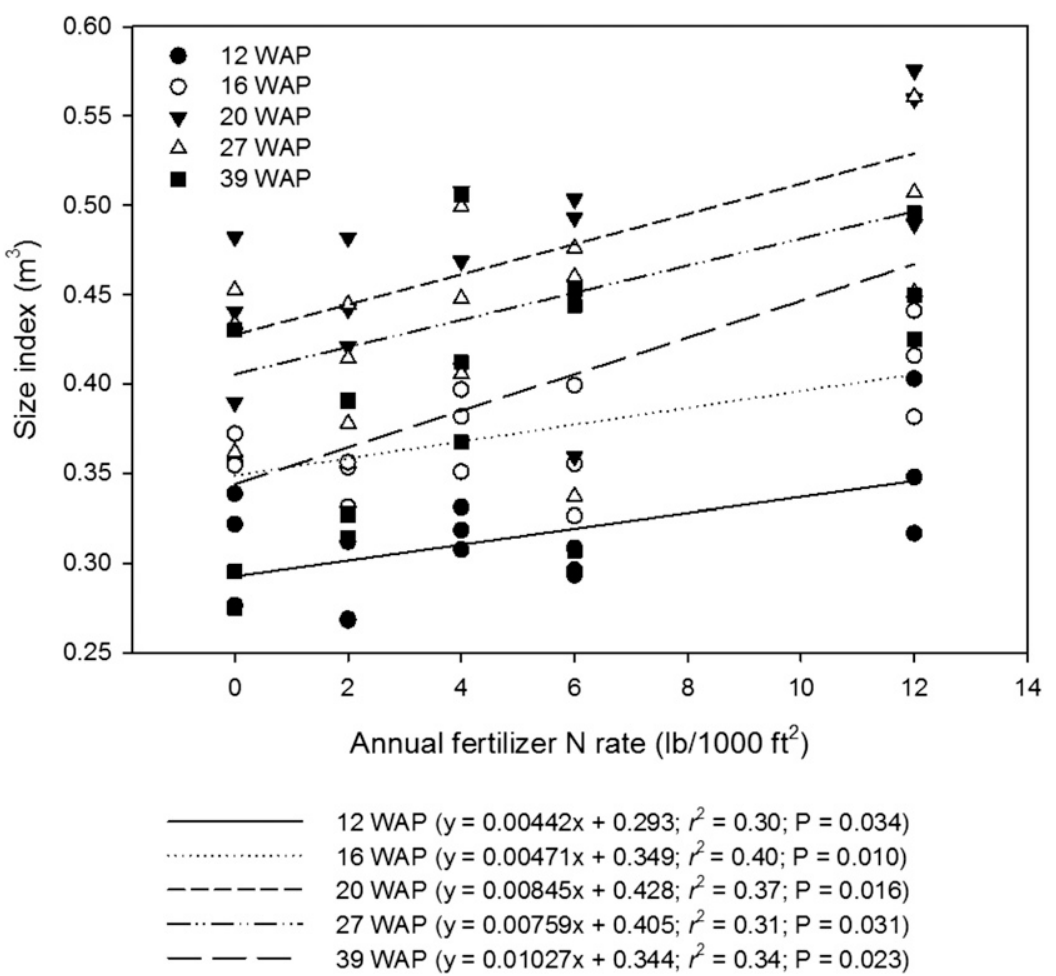

Fig. 1. Rose size index response to fertilizer-derived nitrogen $(\mathrm{N})$ rate at $12,16,20$, 27, and 39 weeks after planting (WAP) when planted in sandy field soil in central Florida; $1 \mathrm{lb} / 1000 \mathrm{ft}^{2}=48.8243 \mathrm{~kg} \cdot \mathrm{ha}^{-1}, 1 \mathrm{~m}^{3}=35.3147 \mathrm{ft}^{3}$.

Table 1. Leaf greenness (SPAD) response of selected landscape-grown shrub species to fertilizer-derived nitrogen $(\mathrm{N})$ rate when planted in St. Augustine fine sand subsoil fill in central Florida.

\begin{tabular}{lccc}
\hline $\begin{array}{l}\text { Species and time after } \\
\text { planting (weeks) }\end{array}$ & Regression equation & $P$ value & $\boldsymbol{r}^{2}$ \\
\hline $\begin{array}{l}\text { Indian hawthorne } \\
\quad 88\end{array}$ & SPAD $=(0.406 \times \mathrm{N}$ rate $)+45.22$ & 0.016 & 0.369 \\
$\begin{array}{l}\text { Rose } \\
\quad 6\end{array}$ & $\mathrm{SPAD}=(0.236 \times \mathrm{N}$ rate $)+45.22$ & 0.035 & 0.236 \\
$\quad 88$ & $\mathrm{SPAD}=(0.330 \times \mathrm{N}$ rate $)+35.94$ & 0.006 & 0.453 \\
Viburnum & & & \\
$\quad 88$ & $\mathrm{SPAD}=(0.840 \times \mathrm{N}$ rate $)+35.45$ & 0.006 & 0.449 \\
$\quad 100$ & $\mathrm{SPAD}=(0.778 \times \mathrm{N}$ rate $)+58.22$ & 0.001 & 0.591 \\
\hline
\end{tabular}

the effect of $\mathrm{N}$ rate on rose SI was best described by the first-order regression at 12, 16, 20,27, and 39 WAP, indicating that maximum size was not achieved by $\mathrm{N}$ applications of up to $12 \mathrm{lb} / 1000 \mathrm{ft}^{2}$ (Fig. 1 ). However, the relationship between SI and fertilizer rate was weak $\left(r^{2} \leq\right.$ 0.40 ), suggesting that other environmental factors contributed to the growth response of rose (Fig. 1). Neither the first- nor the second-order polynomial regression equations were significant for the SI or biomass response of roses from 48 WAP through the end of the study (data not shown). point during the study (data not shown).

Plant Quality ratings. Plant quality response to $\mathrm{N}$ fertilization rate varied by species. No $\mathrm{N}$ rate effect on visual quality of viburnum was reported from 0 to 24 WAP. Beginning at $27 \mathrm{WAP}$, quality of viburnum receiving $\mathrm{N}$ at 0 or $2 \mathrm{lb} /$ $1000 \mathrm{ft}^{2}$ annual rates was usually lower than plants receiving $12 \mathrm{lb} / 1000 \mathrm{ft}^{2}$ (Table 2). Similarly, there was little $\mathrm{N}$ fertilizer effect on the quality of roses from 7 to 31 WAP. After 39 WAP (except $62 \mathrm{WAP}$ ), roses receiving $4 \mathrm{lb} / 1000 \mathrm{ft}^{2}$ of $\mathrm{N}$ annually exhibited higher quality than shrubs fertilized with 0 or $2 \mathrm{lb} / 1000 \mathrm{ft}^{2}$; no additional quality improvement was reported for plants fertilized with $\mathrm{N}$ at 6 or $12 \mathrm{lb} / 1000 \mathrm{ft}^{2}$ per year (Table 1). However, visual quality of viburnum and roses was acceptable (quality ratings of 3 ) or greater during most weeks until 76 WAP, regardless of the amount of $\mathrm{N}$ applied (Table 2). From 76 to 100 WAP, the quality of viburnum was typically lower than 3 when plants received 0 (88 and $100 \mathrm{WAP}$ ) or $2 \mathrm{lb} / 1000 \mathrm{ft}^{2}$ (76 and 100 WAP) of $\mathrm{N}$ annually (Table 2 ). Rose quality also declined after 76 WAP, with most plants failing to rate higher than 3 when fertilized at the 0 or $2 \mathrm{lb} / 1000 \mathrm{ft}^{2}$ annual $\mathrm{N}$ rate; roses fertilized at the higher $\mathrm{N}$ rates maintained quality ratings of 3 or better during this period (Table 2). Nitrogen rate had little to no effect on visual quality of indian hawthorne from 7 to 12 WAP. After $16 \mathrm{WAP}$, the highest quality indian hawthorne was generally produced at the $12 \mathrm{lb} / 1000 \mathrm{ft}^{2}$ annual $\mathrm{N}$ rate when compared with other $\mathrm{N}$ rates (Table 2 ).

\section{Discussion}

Our results were similar to those presented in earlier studies evaluating growth response of woody ornamentals to applied $\mathrm{N}$ fertilizers (Broschat et al., 2008; Ferrini and Baietto, 2006; Gilman, 2011; Gilman and Yeager, 1990; Harris et al., 2008; Rose and Joyner, 2003), which suggested shrubs require little if any $\mathrm{N}$ for growth during the first years after planting. For example, Day and Harris (2007) found that $\mathrm{N}$ fertilizer applied at a rate of 3 or $6 \mathrm{lb} / 1000 \mathrm{ft}^{2}$ annually for 3 years after transplant did not affect growth parameters (trunk growth, shoot extension, or leaf $\mathrm{N}$ 
Table 2. Visual quality of selected landscape-grown shrub species to fertilizerderived nitrogen $(\mathrm{N})$ rate when planted in St. Augustine fine sand subsoil fill in central Florida.

\begin{tabular}{|c|c|c|c|}
\hline \multirow{2}{*}{$\begin{array}{l}\text { Time after planting }(\text { weeks }) \text { and } \\
\text { fertilizer } N \text { rate }\left(1 \mathrm{~b} / 1000 \mathrm{ft}^{2}\right)^{\mathrm{z}}\end{array}$} & \multicolumn{3}{|c|}{ Plant quality $(0-5 \text { scale })^{y}$} \\
\hline & Indian hawthorne & Rose & Sweet viburnum \\
\hline \multicolumn{4}{|l|}{$7 \mathrm{WAP}^{\mathrm{x}}$} \\
\hline 0 & 4.2 & 4.0 & 4.8 \\
\hline 2 & 4.4 & 4.3 & 4.8 \\
\hline 4 & 4.2 & 3.9 & 4.9 \\
\hline 6 & 4.3 & 4.2 & 4.7 \\
\hline 12 & 4.6 & 3.9 & 4.9 \\
\hline \multicolumn{4}{|l|}{$12 \mathrm{WAP}$} \\
\hline 0 & 3.7 & 3.4 & 4.2 \\
\hline 2 & 3.8 & 3.6 & 4.0 \\
\hline 4 & 3.7 & 3.3 & 3.9 \\
\hline 6 & 3.8 & 3.7 & 4.2 \\
\hline 12 & 4.1 & 3.6 & 4.2 \\
\hline \multicolumn{4}{|l|}{$16 \mathrm{WAP}$} \\
\hline 0 & $3.4 \mathrm{ab}^{\mathrm{w}}$ & 2.9 & 3.8 \\
\hline 2 & $3.6 \mathrm{ab}$ & 3.0 & 3.8 \\
\hline 4 & $3.4 \mathrm{ab}$ & 3.0 & 3.7 \\
\hline 6 & $3.3 \mathrm{~b}$ & 3.1 & 3.8 \\
\hline 12 & $3.8 \mathrm{a}$ & 3.4 & 4.2 \\
\hline \multicolumn{4}{|l|}{$20 \mathrm{WAP}$} \\
\hline 0 & 3.4 & $3.2 \mathrm{~b}$ & 3.3 \\
\hline 2 & 3.5 & $3.4 \mathrm{ab}$ & 3.1 \\
\hline 4 & 3.6 & $3.6 \mathrm{ab}$ & 3.3 \\
\hline 6 & 3.4 & $3.7 \mathrm{ab}$ & 3.6 \\
\hline 12 & 3.9 & $3.8 \mathrm{a}$ & 3.6 \\
\hline \multicolumn{4}{|l|}{$24 \mathrm{WAP}$} \\
\hline 0 & $3.4 \mathrm{~b}$ & 3.4 & 3.5 \\
\hline 2 & $3.4 \mathrm{~b}$ & 3.2 & 3.2 \\
\hline 4 & $3.7 \mathrm{ab}$ & 3.8 & 3.4 \\
\hline 6 & $3.4 \mathrm{~b}$ & 3.3 & 3.7 \\
\hline 12 & $4.1 \mathrm{a}$ & 3.7 & 3.8 \\
\hline \multicolumn{4}{|l|}{27 WAP } \\
\hline 0 & $3.4 \mathrm{ab}$ & 2.9 & $3.2 \mathrm{ab}$ \\
\hline 2 & $3.4 \mathrm{ab}$ & 2.6 & $2.8 \mathrm{~b}$ \\
\hline 4 & $3.7 \mathrm{ab}$ & 2.9 & $3.3 \mathrm{ab}$ \\
\hline 6 & $3.2 \mathrm{~b}$ & 2.8 & $3.2 \mathrm{ab}$ \\
\hline 12 & $3.8 \mathrm{a}$ & 3.1 & $3.6 \mathrm{a}$ \\
\hline \multicolumn{4}{|l|}{$31 \mathrm{WAP}$} \\
\hline 0 & $3.1 \mathrm{~b}$ & 3.0 & $2.9 \mathrm{ab}$ \\
\hline 2 & $3.3 \mathrm{~b}$ & 2.9 & $2.6 \mathrm{~b}$ \\
\hline 4 & $3.3 \mathrm{ab}$ & 3.3 & $3.2 \mathrm{ab}$ \\
\hline 6 & $3.0 \mathrm{~b}$ & 3.1 & $3.6 \mathrm{a}$ \\
\hline 12 & $3.9 \mathrm{a}$ & 3.6 & $3.5 \mathrm{a}$ \\
\hline \multicolumn{4}{|l|}{39 WAP } \\
\hline 0 & $4.5 \mathrm{ab}$ & $3.1 \mathrm{~b}$ & $3.2 \mathrm{c}$ \\
\hline 2 & $4.6 \mathrm{ab}$ & $3.1 \mathrm{~b}$ & $3.4 \mathrm{bc}$ \\
\hline 4 & $4.7 \mathrm{ab}$ & $4.1 \mathrm{a}$ & $4.2 \mathrm{a}$ \\
\hline 6 & $4.2 \mathrm{~b}$ & $3.9 \mathrm{ab}$ & $4.0 \mathrm{ab}$ \\
\hline 12 & $4.9 \mathrm{a}$ & $3.8 \mathrm{ab}$ & $4.4 \mathrm{a}$ \\
\hline \multicolumn{4}{|l|}{48 WAP } \\
\hline 0 & 3.6 & $3.2 \mathrm{~b}$ & $3.3 \mathrm{~b}$ \\
\hline 2 & 3.6 & $3.2 \mathrm{ab}$ & $3.3 \mathrm{~b}$ \\
\hline 4 & 3.4 & $3.8 \mathrm{ab}$ & $3.9 \mathrm{ab}$ \\
\hline 6 & 3.3 & $3.7 \mathrm{ab}$ & $3.9 \mathrm{ab}$ \\
\hline 12 & 3.9 & $4.0 \mathrm{a}$ & $4.3 \mathrm{a}$ \\
\hline
\end{tabular}

(Continued on next page) content) of red maple (Acer rubrum) and littleleaf linden (Tilia cordata) trees. Similarly, Harris et al. (2008) reported no effect of $\mathrm{N}$ fertilization on posttransplant growth or rate of establishment of 10 shade tree species, even when grown in poor-quality urban soils. Perry and Hickman (1992) also found no increase in growth of valley oak (Quercus lobata) when fertilized with $\mathrm{N}$ at planting and at 1 year after planting into a Bear Creek clay loam soil (fine-loamy, mixed, superactive, thermic Typic Endoaqualfs). The authors suggested that soil fertility was adequate to sustain adequate growth during this period.

In contrast, some researchers have reported increases in growth parameters of woody ornamentals with the addition of fertilizer (Gilman and Yeager, 1990; Gilman et al., 2000; Lloyd et al., 2006; Neely, 1980; Schulte and Whitcomb, 1975). For example, seedling southern magnolia (Magnolia grandiflora) and fieldgrown live oak (Quercus virginiana) trees grew faster when fertilized with $\mathrm{N}$ on sandy, low fertility, central Florida soils (Gilman et al., 2000). Likewise, Rose and Joyner (2003) and Neely (1980) reported greater increases in growth of fertilized woody landscape plants on lower fertility soils. Broschat et al. (2008) reported the appearance of nutrient deficiency symptoms in areca palm (Dypsis lutescens) $\cong 6$ to 8 months after transplant. Because roots of container-grown shrubs are confined to the planting hole for several months after planting (Shober et al., 2009b; Wiese et al., 2009), fertilizers applied to plants in the potting substrate are likely depleted quickly during establishment. Therefore, based on the results of our work and other studies, it appears that the fertility of our field soils (rather than the potting substrate) was adequate to support the establishment growth of the woody ornamental species. However, it is possible that a growth response of evaluated shrubs to $\mathrm{N}$ fertilizer would be observed if shrubs were transplanted into lower fertility soils or subsoil fill material instead of field soils.

We reported little to no growth response of shrub species to $\mathrm{N}$ in year 1 or 2 of the study; however, some researchers reported increases in growth when $\mathrm{N}$ inputs are supplied in the first year (Ferrini and Baietto, 
Table 2. (Continued) Visual quality of selected landscape-grown shrub species to fertilizer-derived nitrogen $(\mathrm{N})$ rate when planted in St. Augustine fine sand subsoil fill in central Florida.

\begin{tabular}{cccc}
\hline Time after planting (weeks) and & \multicolumn{3}{c}{ Plant quality $(\mathbf{0}-\mathbf{5} \text { scale })^{\mathbf{y}}$} \\
\cline { 2 - 4 } fertilizer N rate $\left(\mathbf{l b} / \mathbf{1 0 0 0} \mathbf{f t}^{2}\right)^{\mathbf{z}}$ & Indian hawthorne & Rose & Sweet viburnum \\
\hline 62 WAP & $3.9 \mathrm{ab}$ & 3.4 & $3.4 \mathrm{~b}$ \\
0 & $3.8 \mathrm{~b}$ & 3.4 & $3.7 \mathrm{ab}$ \\
2 & $3.6 \mathrm{~b}$ & 3.7 & $4.1 \mathrm{ab}$ \\
4 & $3.6 \mathrm{~b}$ & 3.8 & $4.0 \mathrm{ab}$ \\
6 & $4.5 \mathrm{a}$ & 3.9 & $4.3 \mathrm{a}$ \\
12 & & & \\
76 WAP & $4.1 \mathrm{ab}$ & $2.6 \mathrm{~b}$ & $3.1 \mathrm{ab}$ \\
0 & $4.1 \mathrm{ab}$ & $2.4 \mathrm{~b}$ & $2.8 \mathrm{~b}$ \\
2 & $3.4 \mathrm{~b}$ & $3.6 \mathrm{a}$ & $3.6 \mathrm{a}$ \\
4 & $3.4 \mathrm{~b}$ & $3.1 \mathrm{ab}$ & $3.1 \mathrm{ab}$ \\
6 & $4.3 \mathrm{a}$ & $3.2 \mathrm{ab}$ & $3.7 \mathrm{a}$ \\
12 & & & \\
88 WAP & $4.4 \mathrm{ab}$ & $2.9 \mathrm{~b}$ & $2.9 \mathrm{~b}$ \\
0 & $4.5 \mathrm{ab}$ & $2.8 \mathrm{~b}$ & $3.1 \mathrm{ab}$ \\
2 & $3.9 \mathrm{~b}$ & $4.5 \mathrm{a}$ & $3.5 \mathrm{ab}$ \\
4 & $4.2 \mathrm{ab}$ & $3.9 \mathrm{a}$ & $3.5 \mathrm{ab}$ \\
6 & $4.7 \mathrm{a}$ & $4.1 \mathrm{a}$ & $3.7 \mathrm{a}$ \\
12 & & & \\
100 WAP & $3.8 \mathrm{a}$ & $2.6 \mathrm{~b}$ & $2.9 \mathrm{~b}$ \\
0 & $3.7 \mathrm{ab}$ & $2.7 \mathrm{~b}$ & $2.8 \mathrm{~b}$ \\
2 & $3.2 \mathrm{ab}$ & $3.7 \mathrm{a}$ & $3.3 \mathrm{ab}$ \\
4 & $3.1 \mathrm{~b}$ & $3.3 \mathrm{ab}$ & $3.6 \mathrm{a}$ \\
6 & $3.7 \mathrm{a}$ & $3.6 \mathrm{a}$ & $3.8 \mathrm{a}$ \\
\hline 2 & & &
\end{tabular}

${ }^{\mathrm{z}} 1 \mathrm{lb} / 1000 \mathrm{ft}^{2}=48.8243 \mathrm{~kg} \cdot \mathrm{ha}^{-1}$

$\mathrm{y}_{0}=$ dead plant, 5 = outstanding plant quality (dense leaf canopy, high-quality flowers, no nutrient deficiencies, no dieback).

${ }^{x} \mathrm{WAP}=$ weeks after planting.

"Mean separation within columns for each species and WAP by Tukey's honestly significant difference test at $P<$ 0.05 .

2006; Schulte and Whitcomb, 1975). In contrast, other researchers saw increases in growth only when fertilizer was supplied in later years. For example, Gilman et al. (2000) reported that $\mathrm{N}$ fertilizer applied at $4.2,8.3$, $12.4,16.5$, or $20.6 \mathrm{lb} / 1000 \mathrm{ft}^{2}$ per year did not influence height or trunk diameter of southern magnolia in years 1 or 2. However, trees receiving $\mathrm{N}$ fertilizer at an annual rate of $8.3 \mathrm{lb} /$ $1000 \mathrm{ft}^{2}$ grew taller than plants receiving $4.2 \mathrm{lb} / 1000 \mathrm{ft}^{2}$ of $\mathrm{N}$ annually. Therefore, it is also possible that the shrub species evaluated in our study could exhibit a growth response to added $\mathrm{N}$ fertilizer in later years.

Although we reported limited growth response of shrubs to added $\mathrm{N}$, visual quality increased late in year 2 (after 76 WAP) when rose and sweet viburnum were fertilized with a minimum of 4 or $6 \mathrm{lb} / 1000 \mathrm{ft}^{2}$ per year, respectively (Table 2 ). Broschat and Moore (2010) reported that unfertilized hibiscus (Hibiscus rosasinesis) had poor quality (as measured by plant color) and reported increased growth and darker color when hibiscus received high rates of $\mathrm{N}\left(75 \mathrm{~g} \cdot \mathrm{m}^{-2}\right.$ of $18 \mathrm{~N}-0.6 \mathrm{P}-6.7 \mathrm{~K}-2.6 \mathrm{Mg}$ compared with $75 \mathrm{~g} \cdot \mathrm{m}^{-2}$ of $8 \mathrm{~N}-0.9 \mathrm{P}-10 \mathrm{~K}-4 \mathrm{Mg}$ ); however, high rates of $\mathrm{N}$ induced magnesium deficiency, which eventually affected plant quality. In contrast, Broschat et al. (2008) found that quality of fertilized dwarf allamanda (Allamanda cathartica 'Hendersoni') fertilized with $\mathrm{N}$ at 8,12 , or $24 \mathrm{lb} / 1000 \mathrm{ft}^{2}$ per year and nandina (Nandina domestica) fertilized with $\mathrm{N}$ at 8,12 , or $16 \mathrm{lb} / 1000 \mathrm{ft}^{2}$ per year was not different from unfertilized plants. Similarly, the quality of all species evaluated here was acceptable or better regardless of $\mathrm{N}$ fertilizer rate before 76 WAP.

Our results suggest that shrub species may need little to no supplemental $\mathrm{N}$ fertilizer during the establishment period (year l) to produce high-quality plants. However, shrub quality may benefit from a low level of $\mathrm{N}$ fertilizer during the second year
(Table 2). Yet, Broschat and Moore (2010) reported that $\mathrm{N}$ fertilizer applied at 6 months after planting continued to affect plant quality at 12 and 24 months after transplant. Werner and Jull (2013) suggested that young trees rely more heavily on fertilizer-derived $\mathrm{N}$ than mature trees, which used previously assimilated $\mathrm{N}$ to meet the requirements. As such, fertilizer-derived $\mathrm{N}$ applied in the early years after planting may provide the woody ornamentals the $\mathrm{N}$ needed to meet the demand in later years. Therefore, we cannot discount the benefits of $\mathrm{N}$ applications during establishment, although we reported little to no quality response of shrubs to fertilizer.

Struve (2002) recommends that fertilizer rates should correspond to the particular goal in the landscape (e.g., correcting a nutrient deficiency, increasing plant growth, or maintaining plant quality). Therefore, we suggest that the visual quality of some shrub species would benefit from annual applications of $\mathrm{N}$ fertilizer at 2 to $4 \mathrm{lb} / 1000 \mathrm{ft}^{2}$; lower rates could support adequate growth and quality for some shrub species. Our recommended rate corresponds with published annual $\mathrm{N}$ fertilizer recommendations for woody ornamentals in the landscape [ 2 to 4 $\mathrm{lb} / 1000 \mathrm{ft}^{2}$ (Smiley et al., 2002); 0 to $1 \mathrm{lb} / 1000 \mathrm{ft}^{2}$ (Gill et al., 2001); and 0.5 to $3 \mathrm{lb} / 1000 \mathrm{ft}^{2}$ (Rose and Joyner, 2003)]. These $\mathrm{N}$ fertilization recommendations suggest applying only small amounts of $\mathrm{N}$ fertilizer, which will prevent $\mathrm{N}$ losses to groundwater without sacrificing plant growth and quality.

\section{Literature cited}

American National Standards Institute (ANSI). 2004. Tree, shrub, and other woody plant maintenance standard practices (fertilization). American National Standard Practices for Tree Care Operations. Amer. Natl. Stnd. Inst., Manchester, NH.

Broschat, T.K. and K.A. Moore. 2010. Effects of fertilization on the growth and quality of container-grown areca palm and chinese hibiscus during establishment in the landscape. HortTechnology 20:389-394.

Broschat, T.K., D.R. Sandrock, M.L. Elliott, and E.F. Gilman. 2008. Effects of fertilizer type on quality and nutrient content of established landscape plants in Florida. Hort Technology 18:278-285. 
Day, S.D. and J.R. Harris. 2007. Fertilization of red maple (Acer rubrum) and littleleaf linden (Tilia cordata) trees at recommended rates does not aid tree establishment. Arboricult. Urban For. 33:113-121.

Ferrini, F. and M. Baietto. 2006. Response to fertilization of different tree species in the urban environment. Arboricult. Urban For. 32:93-99.

Florida Department of Environmental Protection. 2010. Florida friendly best management practices for protection of water resources by the green industries. 29 Aug. 2013. <http://fyn.ifas.ufl.edu/ pdf/GIBMP_Manual_WEB_2_17_11.pdf $>$.

Gill, S., R. Bosmans, and W. MacLachlan. 2001. Fertilizer recommendations for landscape trees and shrubs. Maryland Coop. Ext. HG23.

Gilman, E.F. 2011. Dispelling misperceptions about trees. Univ. Florida, Inst. Food Agr. Sci. SSORH3.

Gilman, E.F. and T.H. Yeager. 1990. Fertilizer type and nitrogen rate affects fieldgrown laurel oak and Japanese ligustrum. Proc. Florida State Hort. Soc. 103:370372.

Gilman, E.F., T.H. Yeager, and D. Kent. 2000. Fertilizer rate and type impacts magnolia and oak growth in sandy landscape soil. J. Arboricult. 26:177-182.

Harris, J.R., S.D. Day, and B. Kane. 2008. Nitrogen fertilization during planting and establishment of the urban forest: A collection of five studies. Urban For. Urban Green. 7:195-206.

Kidder, G., E.A. Hanlon, T.H. Yeager, and G.L. Miller. 2009. IFAS standardized fertilization recommendations for environmental horticulture crops. Univ. Florida, Inst. Food Agr. Sci. SL141.

Lloyd, J.E., D.A. Herms, M.A. Rose, and J. Van Wagoner. 2006. Fertilization rate and irrigation scheduling in the nursery influence growth, insect performance, and stress tolerance of 'Sutyzam' crabapple in the landscape. HortScience 41:442-445.

Mulvaney, R.L. 1996. Nitrogen-Inorganic forms, p. 1123-1184. In: D.L. Sparks, A.L. Page, P.A. Hemlke, R.H. Loeppert, P.N. Soltanpour, A. Tabatabai, C.T. Johnston, and M.E. Sumner (eds.). Methods of soil analysis, Part 3: Chemical methods. Soil Sci. Soc. Amer., Madison, WI.

Mylavarapu, R.S. 2009. UF/IFAS Extension soil testing laboratory (ESTL) analytical procedures and training manual. Univ. Florida, Inst. Food Agr. Sci. Circular 1248.

Neely, D. 1980. Tree fertilization trials in Illinois. J. Arboricult. 6:271-273.

Perry, E. and G.W. Hickman. 1992. Growth response of newly planted valley oak trees to supplemental fertilizers. J. Environ. Hort. 10:242-244.

Rose, M.A. 1999. Nutrient use patterns in woody perennials: Implications for increasing fertilizer efficiency in fieldgrown and landscape ornamentals. HortTechnology 9:613-617.

Rose, M.A. and B. Biernacka. 1999. Seasonal patterns of nutrient and dry weight accumulation in freeman maple. HortScience 34:91-95.

Rose, M.A. and B. Joyner. 2003. TruGreen Chemlawn research on fertilization of woody ornamentals, p. 121-126. In: A. Siewert, A. Siewert, B. Rao, and D. Marion (eds.). Tree and shrub fertilization: Proceedings from an international conference on tree and shrub fertilization. Intl. Soc. Arboricult., Champaign, IL.

Schulte, J.R. and C.E. Whitcomb. 1975. Effects of soil amendments and fertilizer levels on the establishment of silver maple. J. Arboricult. 1:192-195.

Shober, A.L., S. Davis, M.D. Dukes, G.C. Denny, S.P. Brown, and S. Vyapari. 2009a. Performance of Florida landscape plants when irrigated by ET-based controllers and time-based methods. J. Environ. Hort. 27:251-256.

Shober, A.L., K.A. Moore, C. Wiese, S.M. Scheiber, E.F. Gilman, M. Paz, M.M. Brennan, and S. Vyapari. 2009b. Posttransplant irrigation frequency affects growth of container-grown sweet viburnum in three hardiness zones. HortScience 44:1683-1687.

Smiley, E.T., S. Lilly, and P. Kelsey. 2002. Tree and shrub fertilization. Intl. Soc. Arboricul., Champaign, IL.
Struve, D.K. 2002. A review of shade tree nitrogen fertilization research in the United States. J. Arboricult. 28:252-263.

U.S. Department of Agriculture (USDA). 2004. Official soil series descriptions. 29 Aug. 2013. <http://soils.usda.gov/ technical/classification/osd/index.html >.

U.S. Environmental Protection Agency (USEPA). 1993a. Method 353.2. Determination of nitrate-nitrite nitrogen by automated colorimetry. Environ. Monitoring Systems Lab., Office Res. Dev., U.S. Environ. Protection Agency, Cincinnati, $\mathrm{OH}$.

U.S. Environmental Protection Agency (USEPA). 1993b. Method 350.1. Determination of ammonia nitrogen by semi-automated colorimetry, EPA-600/ 4-79-020. Environ. Monitoring Systems Lab., Office Res. Dev., U.S. Environ. Protection Agency, Cincinnati, $\mathrm{OH}$.

U.S. Environmental Protection Agency (USEPA). 1993c. Method 351.2. Determination of total Kjeldahl nitrogen by semi-automated colorimetry. Environ. Monitoring Systems Lab., Office Res. Dev., U.S. Environ. Protection Agency, Cincinnati, $\mathrm{OH}$.

University of Florida. 2013. Florida automated weather network, report generator. 29 Aug. 2013. <http://fawn.ifas.ufl. edu/data/reports/>.

van de Werken, H. and J.G. Warmbrod. 1969. Responses of shade trees to fertilization. Tennessee Farm Home Sci. Prog. Report no. 72.

van de Werken, H. 1981. Fertilization and other factors enhancing the growth of young shade trees. J. Arboricult. 7:33-37.

Werner, L.P. and L.G. Jull. 2013. Fertilizer nitrogen uptake and partitioning in young and mature common hackberry (Celtis occidentalis) trees. Arboricult. Urban For. 39:85-93.

Wiese, C.L., A.L. Shober, E.F. Gilman, M. Paz, K.A. Moore, S.M. Scheiber, M.M. Brennan, and S. Vyapari. 2009. Effects of irrigation frequency during establishment on growth of Ilex cornuta 'Burfordii Nana' and Pittosporum tobira 'Variegata' HortScience 44:1438-1443. 